\title{
Production of Bioethanol from Bore (Alocasia macrorrhiza)
}

Producción de bioetanol a partir de oreja de elefante gigante (Alocasia macrorrhiza)

Produção de bioetanol a partir da orelha-de-elefante-gigante (Alocasia macrorrhiza)

\section{Elkin Darío Díaz Díaz ${ }^{1}$ Salma Rosa Quinto Solis ${ }^{2}$}

Received: April $17^{\text {th }}, 2019$

Accepted: July 25th 2019 Available: September 16 ${ }^{\text {th }}, 2019$

How to cite this article: E. D. Díaz Díaz and S. R. Quinto Solis, "Production of Bioethanol from Bore (Alocasia macrorrhiza)," Revista Ingeniería Solidaria, vol. 15, no. 3, 2019. doi: https://doi.org/10.16925/2357-6014.2019.03.03

Artículo de investigación. https://doi.org/10.16925/2357-6014.2019.03.03

1 National University of Colombia, Medellín, Colombia.

ORCID: https://orcid.org/0000-0002-4529-3017

E-mail: eddiazd@unal.edu.co

2 Technological University of Chocó Diego Luis Córdoba, Chocó, Colombia.

ORCID: https://orcid.org/0000-0001-7186-4074 


\section{Abstract}

Introduction: This publication is the product of research entitled "Production of Bioethanol from Bore" developed in the year 2016 at the National University of Colombia in Medellín, Colombia.

Objective: To reduce the emissions of gases produced by the combustion of petrol by use of a 90:10 fuel-ethanol mixture from the bioethanol obtained from the Bore plant (Alocasia macrorrhiza). Methodology: The process for obtaining ethanol involves pretreatment of the raw material through washing and husking, liquefied, pre-drying, pre-shredding, drying, crushing and sifting and later a microbial fermentation using the Yeast Saccharomyces cerevisiae.

Conclusions: The admixtures of bioethanol in 90:10 fuel-bioethanol mixtures generated an increase in the quality of the fuel, due to the oxygen present in the mixture which improves the combustion.

Following this work, it is concluded that Bore (Alocasia macrorrhiza) is a promising raw material in the production of a bioethanol with the highest concentrations of starch and better results from fermentation with Saccharomyces cerevisiae.

Originality: To provide a new unknown raw material to produce a bioethanol destined for mixtures with gasoline. Limitations: The general lack of knowledge of the plant, commonly called a weed, in addition to few references related to its use in the production of bioethanol.

Key words: Bioethanol, Bore, Fermentation, Pretreatment, Global warming

\section{Resumen}

Introducción: Este artículo deriva de un trabajo realizado por Arias Jara como trabajo de grado en el 2016 en la universidad central de Ecuador, "Obtención del almidón de la Alocasia macrorrhiza y cuantificación del oxalato de calcio".

Objetivo: Disminuir las emisiones de gases producidos por la combustión de la gasolina mediante la mezcla 90:10 comburente-etanol a partir del bioetanol obtenido del Bore (Alocasia macrorrhiza).

Metodología: El proceso para la obtención de etanol involucra un pretratamiento de la materia prima a través de lavado y descascarado, licuado, pre-secado, pre-triturado, secado, triturado y cernido y posteriormente una fermentación microbiana utilizando la levadura Saccharomyces cerevisiae.

Conclusiones: Las adiciones de bioetanol en mezclas 90:10 comburente, bioetanol generó un aumento en la calidad del combustible, debido al oxígeno presente en la mezcla lo que mejora la combustión.

A raíz de este trabajo se concluye que el Bore (Alocasia macrorrhiza) es la materia prima promisoria en la producción de un bioetanol con las concentraciones más elevadas de almidón y mejores resultados a partir de fermentación con Saccharomyces cerevisiae.

Originalidad: Proporcionar una nueva materia prima para la producción de un bioetanol destinado para las mezclas con la gasolina.

Limitaciones: El desconocimiento de la planta la cual comúnmente es llamada maleza, además de las pocas referencias hacia la parte de producción de bioetanol.

Palabras claves: Bioetanol, Bore, Fermentación, Pretratamiento, Calentamiento global.

\section{Resumo}

Introdução: este artigo deriva do trabalho "Obtenção do amido da Alocasia macrorrhiza e quantificação do exalato de cálcio", realizado por Arias Jara como trabalho de graduação em 2016 na Universidade Central do Equador. 
Objetivo: diminuir as emissões de gases produzidos pela combustão da gasolina por meio da mistura 90:10 de comburente-etanol a partir do bioetanol obtido da orelha-de-elefante-gigante (Alocasia macrorrhiza).

Metodologia: o processo para a obtenção de etanol envolve um pré-tratamento da matéria-prima por meio de lavagem e retirada da casca, liquidificação, pré-secagem, pré-trituração, secagem, trituração e peneiração e, posteriormente, uma fermentação microbiana com uso de levedura Saccharomyces cerevisiae.

Conclusões: as adições de bioetanol em 90:10 de comburente e bioetanol gerou um aumento na qualidade do combustível devido ao oxigênio presente na mistura, que melhora a combustão.

Conclui-se com este trabalho que a orelha-de-elefante-gigante (Alocasia macrorrhiza) é a matéria-prima promissora na produção de um bioetanol com as concentrações mais elevadas de amido e melhores resultados a partir da fermentação com Saccharomyces cerevisiae.

Originalidade: proporcionar uma nova matéria-prima para a produção de um bioetanol destinado para as misturas com a gasolina.

Limitações: o desconhecimento da planta, que costuma ser considerada uma praga, além das poucas referências com respeito à produção de bioetanol.

Palavras-chave: Bioetanol, orelha-de-elefante-gigante, fermentação, pré-tratamento, aquecimento global.

\section{INTRODUCTION}

The constant advances of humanity have generated a great rise in industrialization and with this, a depletion of available resources. At present, fossil materials are one of the greatest sources of energy, but they have a limit [1]. In addition, its use generates polluting gases detrimental to health and the environment, reaching a point of no-return in the recovery of ecosystems.

One of the most obvious pollutants are the gases produced by industries and the various means of transport; These greenhouse gases concentrate in the atmosphere and lead to the heating of the Earth's crust. Vehicles using fossil fuels, in this case gasoline, are among the largest producers of these gases [1]. As a result of this problem, the search for new alternatives to mitigate this pollution has begun. The possibility of creating a high-performance biofuel that can be used as an additive for gasoline or a lubricant for the engine has generated a great boom in industrialized countries [2]. The mixture with gasoline aims to reduce emissions of gases such as carbon monoxide and dioxide, along with other pollutants resulting from combustion.

In the search for this solution, the quantities of starch present in different substrates were analyzed. It was found that Bore (Alocasia Macrorrhiza), a plant of tropical origin, has the highest quantities of this polysaccharide, which generates much more product (ethanol) and a much higher-quality final product. By processing the raw material, through fermentation and distillation processes, an ethanol of very high concentrations is obtained. This helps to greatly reduce the quantities of gases emitted by the gasoline. This ethanol has better characteristics than conventional ones 
such as sugar cane, cassava, maize, achira, potato, among others, presenting higher productivity, efficiency and yield [3].

\section{LITERATURE REVIEW}

High emissions from fossil fuels led to biotechnological research in order to improve processes for reducing these pollutants. Bioethanol is an oxidizer obtained from organic material from either agricultural waste or cultivated raw material. The author in article [2], mentions the use of the cassava in industrial processes for the production of bioethanol, optimizing the process using enzymes and a method of joint extraction with simultaneous fermentation.

The author in [3], refers to pretreatments used in cassava to obtain better starch levels from it; processes which are very similar to those used in other tubers from which the proper temperature controls, $\mathrm{pH}$, mills' revolutions, sieve types and crushed type could be observed and performed, among other factors that are very important for the proper treatment of these raw materials.

Article [4 ] carries out a study of starch obtained from various tubers found in Mexico, the purpose of which is a chemical and functional characterization of them, as well as a view of their microscopic appearance, generating statistical and comparative data regarding which tuber is best used in the food sector or any other industrial expansion. Authors in [5] describe a study of ethanol production from sugar cane in which they can have a clearer view of the role of bioethanol in different countries, not only in Colombia. It also provides clear and accurate data on the benefits of production, productivity and viability of the ethanol extraction process from this raw material, which today is one of the main substrates for this purpose.

According to Law 693 of 2001 of Colombia presented in [6], from that year, on gasoline; for cities with more than 500.000 habitants, oxygenants, such as fuel alcohols, will have to be mixed with fuels in a quantity established by the Ministry of Mines and Energy, starting with a concentration of $5 \%$ until eventually reaching $10 \%$ over time. This is in keeping with other countries involved in biotechnology such as Brazil.

Ethanol when mixed with gasoline generates a biofuel of great energy density, improving the engine performance due to the oxygenants present in the mixture, thereby making the conversion of thermal energy into mechanical energy more efficient. It also produces a reduction in fuel consumption and a reduction in pollutants such as NOx, SOx, CO, CO2, between 10-15\% and a decrease of PM2.5 and PM10; such mixtures are E5 and E10 (5 and $10 \%$ ) respectively, this is discussed by the author in Article [7]. 


\subsection{Work developed with the Bore plant}

In 2002, authors in [8] carried out a detailed study of the taxonomy of Alocasia macrorrhiza (Bore) following the research previously carried out by $(\mathrm{L})$ Schott. It focused on the agricultural sector and carried out nutritional analyses for each part of the plant. In the article "Obtaining starch from Alocasia macrorrhiza and quantification of calcium oxalate", the author in [9], carried out a general review of the Bore and a quantification of the percentages of starch and calcium oxalates via laboratory testing, generating a more general vision of the agricultural use of this plant with comments about missing analyses, steps to follow and the right way to proceed with its commercialization.

The author of article [10] idealized a theoretical process for obtaining ethanol from Bore with a method of fermentation and distillation that will give the product the concentration necessary to use it as a fuel for ecological chimneys of interior spaces. Additionally, this article seeks new alternatives for bioethanol production in Colombia highlighting that, at the industrial level, such production does not have to be $100 \%$ sugar cane, proposing plants with a lot of potential but that have been more or less ignored up until now, such as Bore.

\section{METHODOLOGY}

\section{1.Raw Material}

Bore is a plant of tropical origin; it is perennial and belongs to the araceae [8] and it can reach up to 5 meters in height and its leaves are up to 1 meter long. It grows very quickly and adapts very easily to different ecosystems. In its tuber it accumulates high concentrations of carbohydrates in the form of starch and its leaves have large amounts of proteins [9]. The Bore adapts to temperatures between $20-35^{\circ} \mathrm{C}$, pH levels between 5-8, grows in marshy or sandy soils, without requiring high amounts of nutrients thereby allowing it to be sown in soils of low fertility. It does not require high amounts of light, so it can photosynthesis in places with low luminosity [8]. 


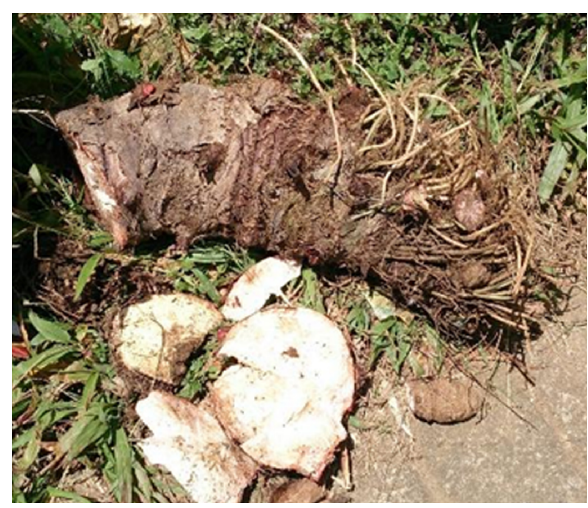

Figure 1. Tuber of Bore (Alocasia macrorrhiza).

Source: own work

Starch is a reserve polysaccharide found in plants. Its structure consists of 2 polysaccharides: amylopectin and amylose [11]. Amylopectin is a branched polymer of glucose units united by a bonds (1-4) and a bonds (1-6). Amylose is a linear polymer of glucose units united by a bonds (1-4) and is insoluble in water [12].
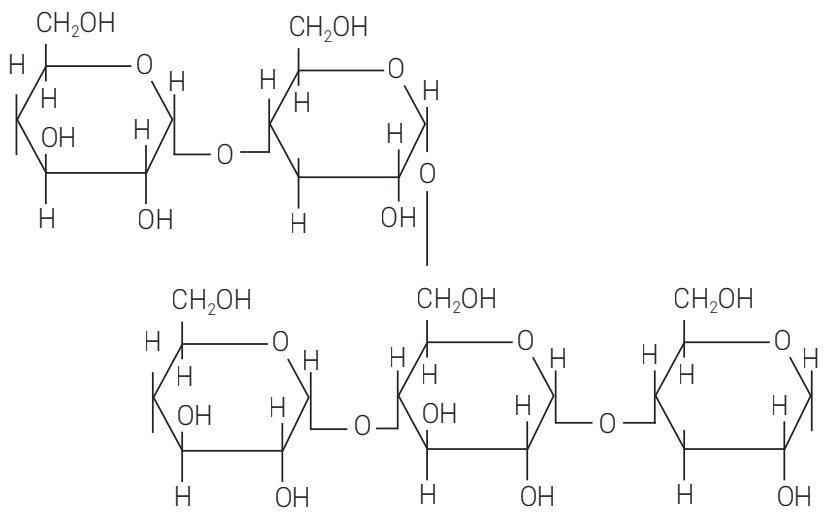

Figure 2. Chain of Starch.

Source: [9]

Starch is extracted mostly from grains of cereals such as sorghum, corn, rice and wheat and from tubers such as achira, Bore, cassava, potato and yams. It is also found in seeds of legumes, fruits and leaves. Among these, tubers have the highest levels of starch [13].

The synthesis of starch is directed by: starch synthetase, branching enzyme (SBE) and ADP-glucose pyrophosphorylate, acting on amylose and amylopectin by uniting and branching the two polysaccharides [14]. 
Bore requires various pretreatment processes (washing and peeling, liquefying, pre-drying, pre-crushing, drying, crushing and sieving) [15].

The liquefying process allows the cell walls to be broken, causing the release of starch molecules. The pre-drying is performed at a temperature of $44^{\circ} \mathrm{C}$, allowing for a certain percentage of humidity in order to permit the rupture of the bonds between the starch and the fiber during the initial separation stages during pre-crushing with a mill for 5 minutes.

The drying process is performed at $60^{\circ} \mathrm{C}$ and $10 \%$ humidity. The sieving is performed with 2 types of sieves at 2 different revolutions until the starch is obtained.

This starch is subjected to temperatures between $74-90^{\circ} \mathrm{C}$ with water until gelatinization occurs.

Enzymatic hydrolysis with glucoamylases and amylases allows D-glucose to be obtained [16], catalysing liquefaction and saccharification processes [17]. Liquefaction is the partial hydrolysis of starch to dextrins with a $\mathrm{pH}$ control in a range of 6-7 and with alpha amylase which is thermotolerant. After this, dextrins are transformed into glucose by means of glucoamylase in the process of saccharification; which has temperature requirements between $50-55^{\circ} \mathrm{C}$ and $\mathrm{pH}$ between $4-5$.

After pretreatment, starch is extracted from the Bore, liquefied and sieved. These processes are of great importance for the quality of the extraction because if the starch is not effectively separated from the fibers, the process has a low yield, and a lot of starch is lost. In the sieve the pulp is separated from the fibrous grout of the Bore.

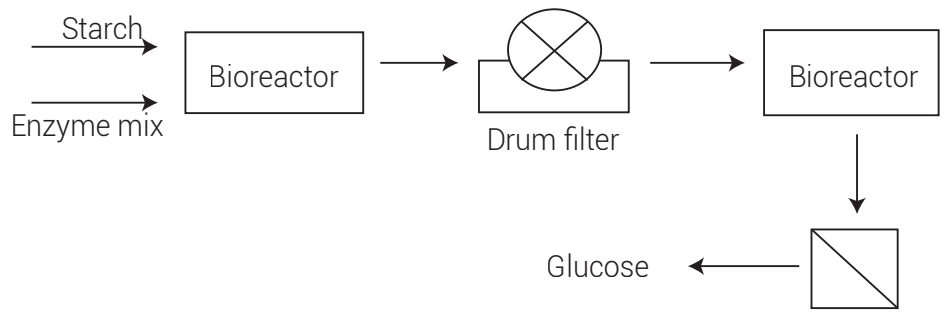

Figure 3. Obtaining Glucose from Starch.

Source: own work

The first reactor begins with the Bore extract obtained from pretreatment. aamylase is added to start the liquefaction process, obtaining dextrins and reducing the viscosity of the solution. The optimal conditions for this process are $\mathrm{pH}: 5$ and a temperature of $80^{\circ} \mathrm{C}$. The filter drum will be in charge of purifying the dextrin obtained from the first procedure without breaking the smaller particles of which it is composed. 
In the second bioreactor, saccharification is performed, which is when dextrin produced in the previous step reacts with glucoamylase to produce D-Glucose. For this process a $\mathrm{pH}$ of 4,5 is required along with a temperature of $70^{\circ} \mathrm{C}$.

\subsection{Microorganism}

Saccharomyces cerevisiae is a eukaryotic belonging to the Fungi kingdom; a yellow-green yeast of globular form. Its life cycle alternates in 2 forms; one diploid and another haploid. It reproduces asexually (gemation). Industrially, it is widely used in food production and is the key ingredient in the fermentation process that converts sugar into alcohol and is used in the production of wines, beers and distillates [18].

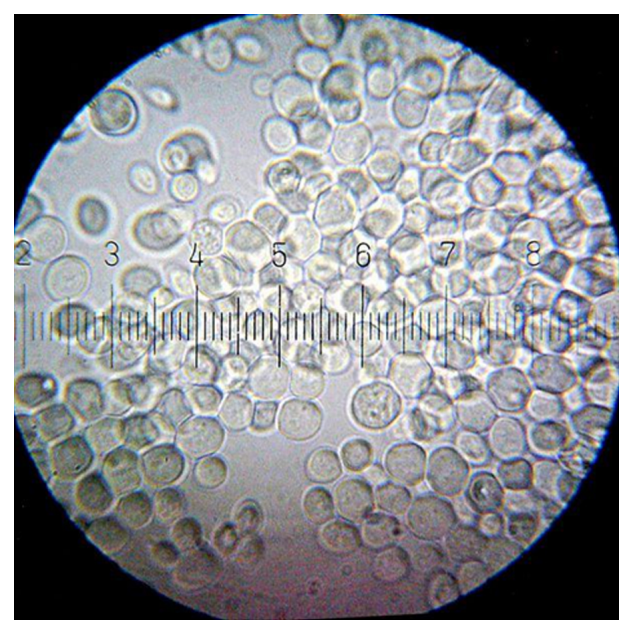

Figure 4. Saccharomyces cerevisiae.

Source: [19]

S. cerevisiae is used for the production of bioethanol industrially as it is a microorganism that is easy to recover and manage, is low cost and is not demanding in terms of its cultivation [20]. It supports high concentrations of ethanol and in fermentation, generates low levels of byproducts, is osmotolerant, able to use high concentrations of sugars, has high cellular viability for recycling and sediment and flocculation characteristics [21].

A home bioreactor, with a maximum volume of 4 liters, was used to produce ethanol. The previously treated substrate was added together with the mixture of enzymes to the bioreactor and inoculated with the microorganism previously activated in Agar Sabouraud. The process was controlled at temperatures between $30-35{ }^{\circ} \mathrm{C}$ and a $\mathrm{pH}$ between 4-6, favouring the growth of the microorganism and the production of ethanol. 


\subsection{Glycolysis}

This enzymatic reaction leads to the degradation of glucose $\left(\mathrm{C}_{6} \mathrm{H}_{12} \mathrm{O}_{6}\right)$, in addition to the formation of ATP, 2 pyruvate molecules $\left(\mathrm{C}_{3} \mathrm{H}_{4} \mathrm{O}_{3}\right)$, and water, which is achieved by 10 reactions [22].

The production of the target metabolite is performed from the glycolysis reaction (Figure 5).

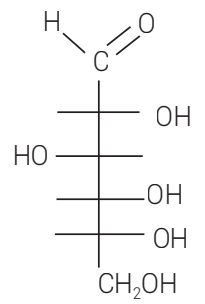

Glucose

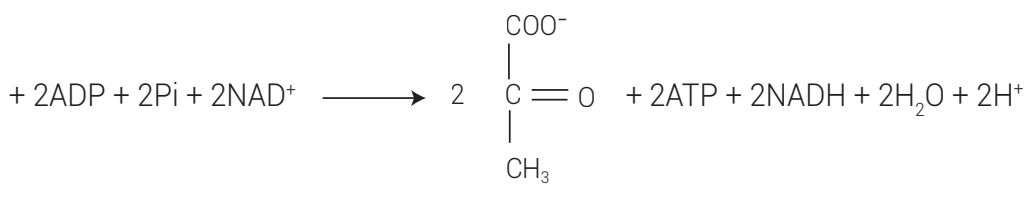

Pyruvate

Figure 5. Overview of glycolysis global reaction.

Source: adapted from [23]

Embden-Meyerhof (glycolysis) is used in the process of fermentation of glucose, until pyruvate is obtained [24]. This is performed by means of a specific mixture of enzymes and an anaerobic environment thereby producing ethanol and carbon dioxide. Glycolysis is a catabolic process whereby pyruvate is obtained from glucose, as shown in Figure 6.

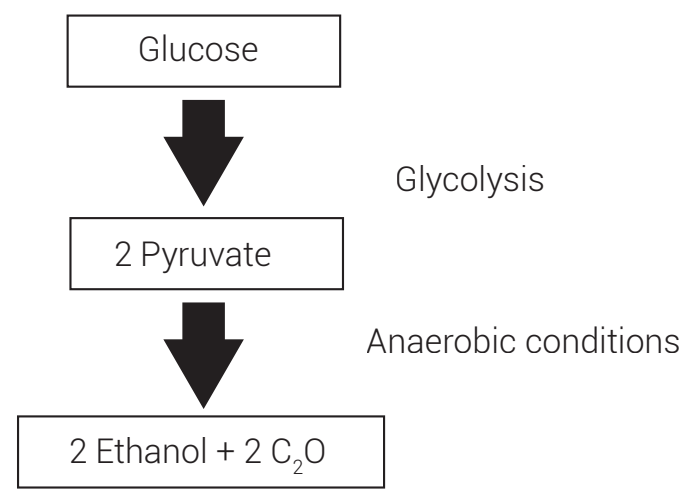

Alcoholic fermentation in yeasts

Figure 6. Catabolic route from pyruvate to ethanol.

Source: [25] 
Pyruvate is decarboxylated due to the enzyme, pyruvate decarboxylase, found in yeast, which is subsequently formed by acetaldehyde. This is reduced to ethanol by the presence of the reducing agent $\mathrm{NADH}$, by the action of the enzyme alcohol dehydrogenase (Figure 7) [26].

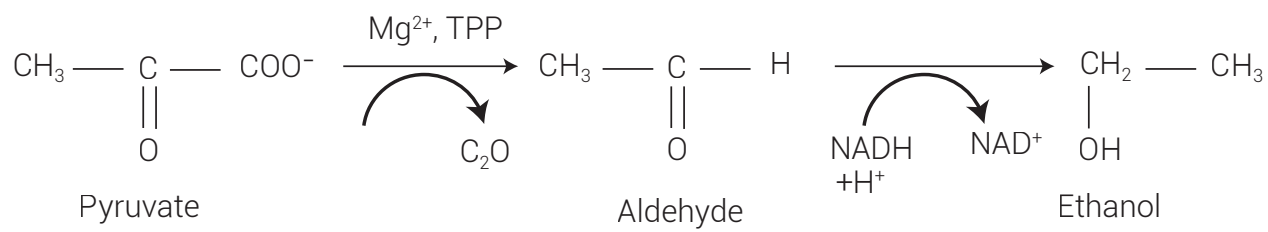

Figure 7. Pyruvate conversion to Ethanol and $\mathrm{CO}_{2}$.

Source: adapted from [26]

The net energy balance is given by:

$\mathrm{C}_{6} \mathrm{H}_{12} \mathrm{O}_{6}+2 \mathrm{ADP}+2 \mathrm{PI}+2 \mathrm{NAD}^{+} \quad 2 \mathrm{C}_{3} \mathrm{H}_{4} \mathrm{O}_{3}+2 \mathrm{ATP}+2 \mathrm{NADH}+\mathrm{H}^{+}+2 \mathrm{H}_{2} \mathrm{O}$. [22]

Glucose to Ethanol Equation:

$$
\mathrm{C}_{6} \mathrm{H}_{12} \mathrm{O}_{6} \quad 2 \mathrm{CH}_{3} \mathrm{CH}_{2} \mathrm{OH}+2 \mathrm{CO}_{2} \text {. [27] }
$$

\section{RESULTS}

Preliminary analysis of different parts of the Bore plant (data not shown) helped determine the place with the highest amount of starch, effectively verifying that the tuber had most of it. When this was extracted, it was found by the dry weight method [28] that $87 \%$ of every $100 \mathrm{~g}$ of the sample is produced.

This polysaccharide is found in many sources, but is mainly obtained from cereals, tubers and legumes. The percentage of this varies depending on the group in which the food is found:

Table 1. Starch content from different types of biomass $(\mathrm{g} / 100 \mathrm{~g})$.

\begin{tabular}{ccc}
\hline Biomass & Starch content & Source \\
\hline Tubers & $55-90$ & Bore, Cassava, potato. \\
\hline Leguminous & $20-45$ & Bean \\
\hline Cereals & $35-80$ & Corn, Wheat. \\
\hline
\end{tabular}

Source: own work 
Tubers are found to be the foods with the highest starch content, indicating a greater use of the substrate.

Table 2. Chemical analysis of tubers (g/100g) Adapted from [29].

\begin{tabular}{cccccc}
\hline Species & Starch & Fiber & Protein & MS & Other \\
\hline Potato & 65.2 & 2.3 & 10.4 & 24.8 & - \\
\hline Yellow Arracacha & 75.6 & 2.85 & 2.86 & 24 & 7.5 \\
\hline Bore & 78 & 3.43 & 6.34 & 34 & 9.9 \\
\hline Red Achira & 74.8 & 2.24 & 3.76 & 30.9 & 9.4 \\
\hline
\end{tabular}

Source: own work

Table 2 shows the chemical analysis of different tubers. The starch content, together with the sugars present, shows great promise for their use as all of these are greater than $60 \%$. Carbohydrates are the source of carbon and energy for microorganisms, so high percentages of this are required. In comparison with the other sources of starch the Bore plant has the highest concentration. Additionally, it has the presence of many ingredients and minerals that do not affect or inhibit the metabolism of the microorganism; making it the optimal raw material for use as a substrate in the production of bioethanol.

The ethanol produced, as measured in a mass spectrum, presented a concentration of $91 \%$ (Figure 8). This concentration is high for the distillation and fermentation method used. An increase of this concentration is projected by optimizing the process using a bioreactor type batch with which the variables of temperature, $\mathrm{pH}$ and agitation are better controlled.

Additions of bioethanol in 90:10 gasoline mixtures led to an increase in fuel quality, due to the oxygen present in the mixture which improves combustion; in addition to the reduction of aromatics, sulphur and olefins. The aromatic content is projected to decrease by $7.045 \%$ in volume, the sulphur by weight of $0.0489 \%$ and the olefins have a reduction of $6.025 \%$ in volume. 

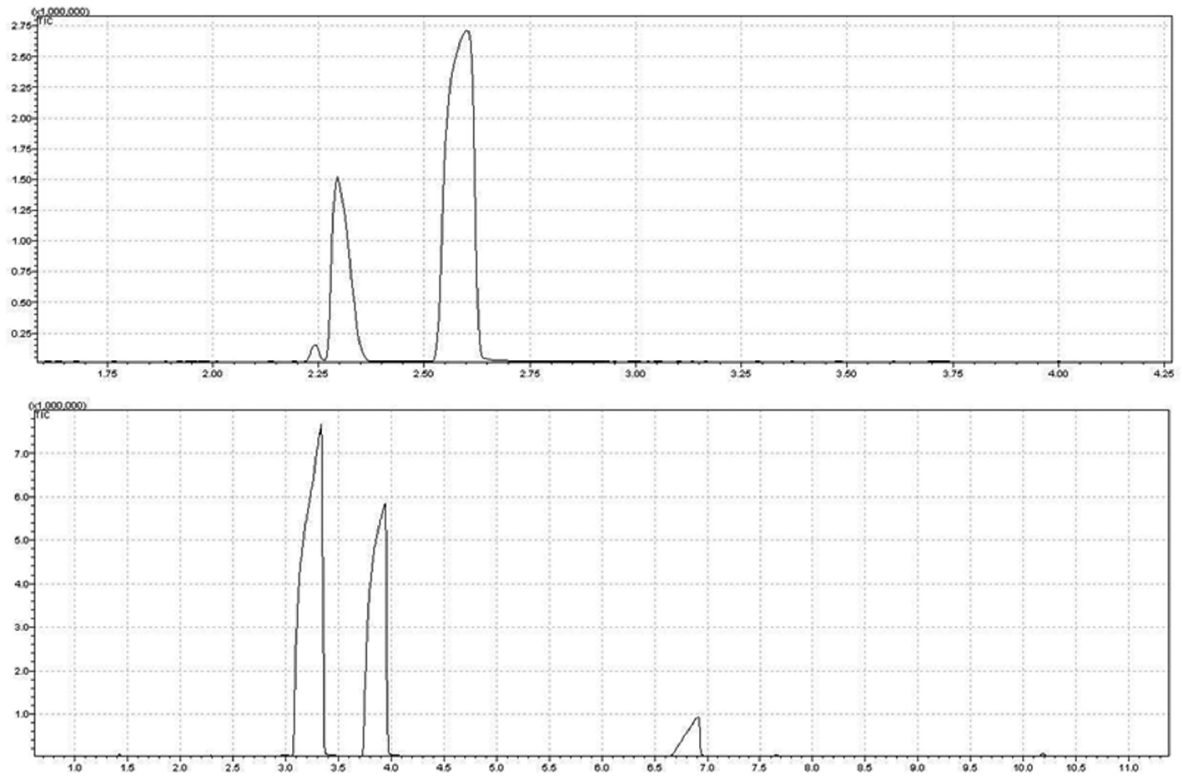

Figure 8. Mass spectrum of the bioethanol produced.

\section{DISCUSSION}

In the various analyses carried out, it was confirmed that Bore has the highest concentrations of starch, in addition to the highest concentration of ethanol of the final product. Throughout this research, searches were carried out in various databases, such as Scopus, ScienceDirect, Nature, Scholar Google, WOS (web of science), Tandfonline (Taylor and Francis Online), among others, and only research related to the cultivation of Bore, its taxonomy and its use in agricultural industry for feeding pigs, broilers and fish was found. There were also articles related to the quantification of starch and calcium oxalates. In the whole state of the art reviewed, there was only one article related to the use of Bore for the production of a bioethanol [10] but this article was only a theoretical proposal implementing a very inefficient methodology. In addition, its treatment of the raw material is inadequate.

The work carried out by Arias Jara [9], "Obtaining starch from Alocasia macrorrhiza and quantifying calcium oxalate" was the reference for this work due to its approach to plant taxonomy, in addition to providing concepts necessary for pre-treatment and data about the starch concentrations present, which generated an approach to the plant leading to the first hypotheses. Progress was made by carrying out the various processes (pre-treatment, treatment, fermentation and distillation) checking 
these concentrations and even variations due to the enzymatic mixtures used. New data was therefore obtained and a very significant advance in the study of ethanol from Bore, discovering a new substrate to implement in 90:10 mixtures, was made .

During ethanol production it was found that the methods used, in addition to the use of a home bioreactor, caused a lot of contamination in the process, which could influence the final outcome. Regardless, the data was generated according to the hypothesis and produced results comparable with those of the literature. It is therefore expected that an improvement and optimization of the process will lead to higher yields and productivity than those obtained.

\section{CONCLUSIONS}

Bore is the optimal raw material as a substrate in the production of bioethanol because it is a very fast-growing plant and, among the most common plants, produces the highest concentrations of starch.

When extracting the starch from the Bore plant and during their subsequent quantification, it was found that for every $100 \mathrm{gr}$ of the sample, $87 \%$ of starch is produced. 2,5 gallons are obtained from a $14 \mathrm{~kg}$ tuber and the concentration obtained from the ethanol produced according to the analysis in the mass spectrum is $91 \%$ while the ethanol produced by sugar cane and maize is $83 \%$ and $85 \%$ respectively [5].

Additions of bioethanol in 90:10 gasoline mixtures led to an increase in fuel quality, improving combustion and reducing the aromatic, sulphur and olefin levels. Such a mixture can be used as a fuel, as it reduces emissions of $\mathrm{CO}, \mathrm{CO} 2$, particulate material, SOx and NOx, and also does not cause engine deterioration, on the contrary, improving its performance.

\section{REFERENCES}

[1] L. Tipanluisa, A. Remache, C. Ayabaca, and S. Reina, "Emisiones Contaminantes de un Motor de Gasolina Funcionando a dos Cotas con Combustibles de dos Calidades," Scielo.conicyt.cl, p. 1. 2017. [Online]. doi: http://dx.doi.org/10.4067/S0718-07642017000100002

[2] H. Castaño and C. Mejía. (2008) Producción de etanol a partir de almidón de yuca utilizando la estrategia de proceso sacarificación-fermentación simultáneas (SSF). [Online]. Available: : https://aprendeenlinea.udea.edu.co/revistas/index.php/vitae/article/viewFile/797/690 
[3] J. Aristizábal, T. Sánchez, and D. Mejía Lorío (2007). Guía técnica para producción y análisis de almidón de yuca. [Online]. Available: http://www.fao.org/3/a-a1028s.pdf

[4] M. Hernández-Medina, J. Torruco-Uco, L. Chel-Guerrero, and D. Betancur-Ancona, "Caracterización fisicoquímica de almidones de tubérculos cultivados en Yucatán, México," 2008. [Online]. doi: http://dx.doi.org/10.1590/S0101-20612008000300031

[5] M. Pons, "Estudio preliminar para producir etanol de la caña de azúcar en la república dominicana," Marinponsasociados.com, 2012. [Online]. Available: http://marinponsasociados. com/PDFMEDIOAMBIENTE/bioetanol.pdf

[6] Minminas.gov.co. (2001). [Online]. Available: https://www.minminas.gov.co/documents/ 10180//23517//21462-3660.pdf.

[7] J. Torres, D. Molina, C. Pinto, and F. Rueda, "Estudio de la mezcla de gasolina con 10\% de etanol anhidro. evaluación de propiedades fisicoquímicas," 2002. [Online]. Available: http:// www.scielo.org.co/scielo.php?script=sci_arttext\&pid=S0122-53832002000100007

[8] M. Gómez, "Una revisión sobre el Bore (Alocasia macrorrhiza)," 2002. [Online]. Available: http://www.fao.org/docrep/006/Y4435S/y4435s0i.htm

[9] M. Arias Jara. (2016) Obtención del almidón de la alocacia macrorrhiza y cuantificación del oxalato de calcio. 1st ed. 2016. [Online]. Available: http://www.dspace.uce.edu.ec/bitstream/25000/7188/1/T-UCE-0017-0034-2016.pdf

[10] P. Maldonado Marín, "Utilización del Bore (Alocasia macrorrhiza) como materia prima para la obtención de bioetanol como combustible de chimeneas ecológicas para interiores". [Online]. Available: https://issuu.com/maosabo/docs/monografia_curso_de_prof._2015

[11] Bertuzzi, M., Armada, M., and Gottifredi, J. (2007). Physicochemical characterization of starch based films. [Online] doi: https://doi.org/10.1016/j.jfoodeng.2006.12.016

[12] A. Peña, Bioquimica, 2nd ed., México, 2005, p.143.

[13] M. Calvo, Estructura del almidón. Bioquímica de los alimentos. [Online]. Available: http:// milksci.unizar.es/bioquimica/temas/azucares/almidon.html

[14] T. Mckee, J. Mckee, and J. González de Buitrago, Bioquímica. Madrid: McGraw-Hill Interamericana, 2005. pp.8, 16-21, 162. 
[15] M. Cobana, and R. Antezana, "Proceso de extracción de almidón de yuca por vía seca," 2007. [Online]. Available: http://www.scielo.org.bo/scielo.php?pid=S0250-546 02007000100014\&script=sci_arttext

[16] A. Hernández, Microbiología industrial. Universidad estatal a Distancia, 2003. [Online]. Available: https://books.google.com.co/books?id=KFq4oEQQjdEC\&pg=PA208\&lpg=PA208 $\& d q=$ licuefaccion+y+sacarificacion\&source=bl\&ots=N-oJRKjZ4o\&sig=7Mzz80CjBtIlt2n9jis L8-Djmfs\&hl=es\&sa=X\&ved=0ahUKEwjVwY3avrDXAhWK4yYKHcZICbMQ6AEIWTAH\#v=onepa ge\&q=licuefaccion\%20y\%20sacarificacion\&f=false

[17] A. Tofiño, "Regulación de la biosíntesis del almidón en plantas terrestres: perspectivas de modificación,” 2006. [Online]. Available: https://revistas.unal.edu.co/index.php/ acta_agronomica/article/view/190/453

[18] S. Garzón Castaño, and C. Hernández Londoño, "Estudio comparativo para la producción de etanol ENTRE Saccharomyces cerevisiae silvestre, Saccharomyces cerevisiae ATCC 9763 Y Candida utilis ATCC 9950". [Online]. Available at: http://repositorio.utp. edu.co/dspace/bitstream/handle/11059/1689/66182g245.pdf;jsessionid=7D082315D9 0B010F5E98733C228DE56?sequence=1

[19] B. Blaylock, "File:20100911 232323 SaccharomycesCerevisiae.jpg," 2012. [Online]. Available: https://microbewiki.kenyon.edu/index.php/File:20100911_232323_Saccharomy cesCerevisiae.jpg

[20] Microbewiki.kenyon.edu. (2014) Saccharomyces cerevisiae - microbewiki. [Online]. Available at: https://microbewiki.kenyon.edu/index.php/Saccharomyces_cerevisiae

[21] E. Fajardo, and S. Sarmiento (2008) Evaluación de melaza de caña como sustrato para la producción de Saccahromyce cereviseae. [Online]. Pontificia Universidad Javeriana de Colombia. Facultad de ciencias Básicas. Microbiología Industrial. 2008. 1st ed. Bogota: Fundación Universitaria Agraria de Colombia. p. 6, 26, 34, 37 . [Online]. Available: https:// www.javeriana.edu.co/biblos/tesis/ciencias/tesis26.pdf

[22] G. Tárano Cartaya, L. Alba Zayas, and D. Núñez. Uvsfajardo.sld.cu. (2013). [Online]. Available: http://www.uvsfajardo.sld.cu/sites/uvsfajardo.sld.cu/files/morfofisiologia_iv_ct_bioqui.pdf

[23] J. Hernández Mora, and J. Acevedo Páez, "Producción de etanol por Saccharomyces cerevisiae a partir de glicerina, subproducto de biodiesel," 2013. [Online]. doi: https://doi. org/10.16925/in.v9i16.532 
[24] D. Raisman, "La respiración celular: destino del ac. pirúvico en ambientes aerobios," 2004. [Online]. Available: http://www.biologia.edu.ar/metabolismo/met5.htm.

[25] S. Yang, X. Liu, and Y. Zhang, "Bioprocessing for Value-Added Products from Renewable Resources," 2007. [Online]. doi: https://doi.org/10.1016/B978-044452114-9/50005-0

[26] M. Eram, and K. Ma, "Decarboxylation of Pyruvate to Acetaldehyde for Ethanol Production by Hyperthermophiles", Decarboxylation of Pyruvate to Acetaldehyde for Ethanol Production by Hyperthermophiles, 2013. [Online]. p. 582-584. doi: https://doi.org/10.3390/biom3030578

[27] M.T. Madigan, J.M. Martinko, and J. Parker, Brock biología de los microorganismos, 10 ed. Carbondale, USA: Pearson Prentice Hall, 2003, pp. 350-370.

[28] S.J. PIRT, Principles of microbe and cell cultivation, chapter 3. Blackwell Scientific Publications, 1975, pp.15-16.

[29] M. Knowles, M. Pabón, and J. Carulla, "Uso de layuca (Manihotesculenta Crantz) y otras fuentes de almidones no convencionales en la alimentación de rumiantes," 2012. [Online]. Available: http://www.scielo.org.co/scielo.php?script=sci_arttext\&pid=S0120-06902012000300016. 